Article

\title{
Does Open Innovation Enhance a Large Firm's Financial Sustainability? A Case of the Korean Food Industry
}

\author{
Harry Jeong ${ }^{1}$, Kwangsoo Shin ${ }^{1, *}$, Eungdo Kim ${ }^{1, * \mathbb{D}}$ and Seunghyun Kim ${ }^{2}$ \\ 1 Department of Biomedical Convergence, College of Medicine, Chungbuk National University, \\ Chungdae-ro 1, Seowon-gu, Cheong-ju, Chungbuk 28644, Korea; harry@g.cbnu.ac.kr \\ 2 Office of Entrepreneurship and Innovation Studies, Science and Technology Policy Institute, Building B, \\ Sejong National Research Complex, 370 Sicheong-daero, Sejong 30147, Korea; shkim@stepi.re.kr \\ * Correspondence: sksidea@chungbuk.ac.kr (K.S.); edkim@chungbuk.ac.kr (E.K.)
}

Received: 7 August 2020; Accepted: 28 September 2020; Published: 1 October 2020

\begin{abstract}
This study aims to explore whether a firm's financial sustainability is enhanced by open innovation especially after a global financial crisis. There are few studies on the relationship between open innovation and financial sustainability. This study aimed to fill the literature gap by analyzing the change in the financial ratio according to the increase or decrease in open innovation. We used a case study method regarding large Korean food firms. Korea is a latecomer in the food industry, which is driven by large companies. This study is meaningful for financial sustainability studies of countries with a lack of resources and small market size, which require open innovation. The findings of this study are as follows: The most preferred alliance strategy of large food firms is joint research. In order to secure raw materials and markets, open innovation was actively conducted abroad, which increased growth and profitability. However, a firm which rarely adopts open innovation could grow steadily through internal strategies. On the other hand, although relatively many open innovations have been used, growth and profitability could decrease. Firms with sufficient absorptive capacity strengthen financial sustainability through open innovation.
\end{abstract}

Keywords: food industry; financial sustainability; open innovation; value chain; financial stability

\section{Introduction}

The food industry is one of the most important sectors of the global economy, which is required to provide a wide range of products at a short delivery date and low cost [1]. The food industry faces a series of challenges: Changes in lifestyles [2], changes in global food consumption patterns [3], and social response to food systems due to environmental, social, and economic issues [4]. These led to a period of structural change [5]. Furthermore, since 2008, the financial crisis in Europe and the US has adversely affected the cost management of food firms in the world. Because most firms import raw materials, machinery, packaging, and other materials needed for food production from abroad, the margin of change in profitability due to the fluctuation of the exchange rate is much greater. One of the major issues in management is managing the risks in this sector, which is heavily influenced by exchange rates and oil prices. As a result, food firms have suffered a double burden of rising raw material costs and falling sales.

The growth of capitalism faces limitations, therefore an approach to a series of problems under the keynote of the Open Innovation Economic System (OIES) is needed to overcome this [6]. Global risks make socio-economic systems more vulnerable to various uncertainties and fluctuations, which makes open innovation even more necessary [7]. Open innovation promotes the introduction of new products 
and services by securing external knowledge and saving costs and time [8]. The food industry was a low technology-intensive industry that required low cooperation, but now it develops products innovatively, supported by other industries' rapid technological change. The industries are using more external knowledge and technology to revitalize it [9]. The food industry has been rapidly changing to a demand-based approach [10] to rapidly accommodate consumers' needs. Building close relationships with the various actors that exist in the food industry value chain is essential to improving the commercial success of products [11]. In addition, it is important that open innovation actually enhances the sustainable growth of individual firms to proactively respond to global environmental changes surrounding the food industry. However, there are few studies focusing on investigating the impact of open innovation on firms' sustainability [12].

Therefore, we conducted a case study of the financial sustainability of food firms. We built a database after the 2008 global financial crisis, which contained information on alliances in four major Korean firms. The data were correlated with each firm's financial ratio. In addition, the trend of the management strategies implemented by firms was studied. The case study of large Korean food firms is suitable for studying firms' sustainable growth through open innovation in the food industry in times of crisis. The Korean food industry is a latecomer to the global food market. It is in a position to chase the United States and Europe. There are few resources in the Korean food industry and there are technological gaps for the first mover, therefore, it is increasingly necessary to adopt an open innovation strategy for latecomer countries rather than for advanced countries in the food industry. The Korean food industry has grown mainly from government-led and is driven by large firms. Due to the technological gap for first movers, insufficient resources, and small market size, more open innovation is needed for the sustainable growth of the Korean food industry. In this context, it is meaningful to study the open innovation and financial sustainability of industry-leading large Korean food firms.

This study contributes to filling the literature gap on open innovation and financial sustainability by analyzing the financial ratio of large food firms that adopted open innovation. Although the economy is in a difficult situation due to reduced productivity, we expect human ingenuity and the transformation process dedicated to sustainability will create new opportunities [13]. This study can be referred to for food firms in many countries that want to adopt open innovation. Governments that support food firms can tailor policies for each firm. Based on this study, researchers can further develop the research for the relationship between open innovation and financial sustainability.

The remainder of the paper is organized as follows: Section 2 presents the theory and background of the food industry and the open innovation trend in this context. Section 3 presents the methodology. Section 4 presents the results of the study, and these are extensively discussed. Finally, Section 5 provides a summary of the study, as well as its implications and limitations.

\section{Industrial Trends and Theoretical Background}

\subsection{Food Industry and Value Chain}

Agricultural, livestock, and marine products, which are the raw materials of food and the food itself, are directly traded as raw materials or delivered to consumers through distributors. "Food" means any substance, whether processed, semi-processed, or raw, that is intended for human consumption, and includes drinks, chewing gum, and any substance that has been used in the manufacture, preparation, or treatment of "food", but does not include cosmetics or tobacco or substances used only as drugs [14]. The value chain of the food industry is shown in Figure 1. 


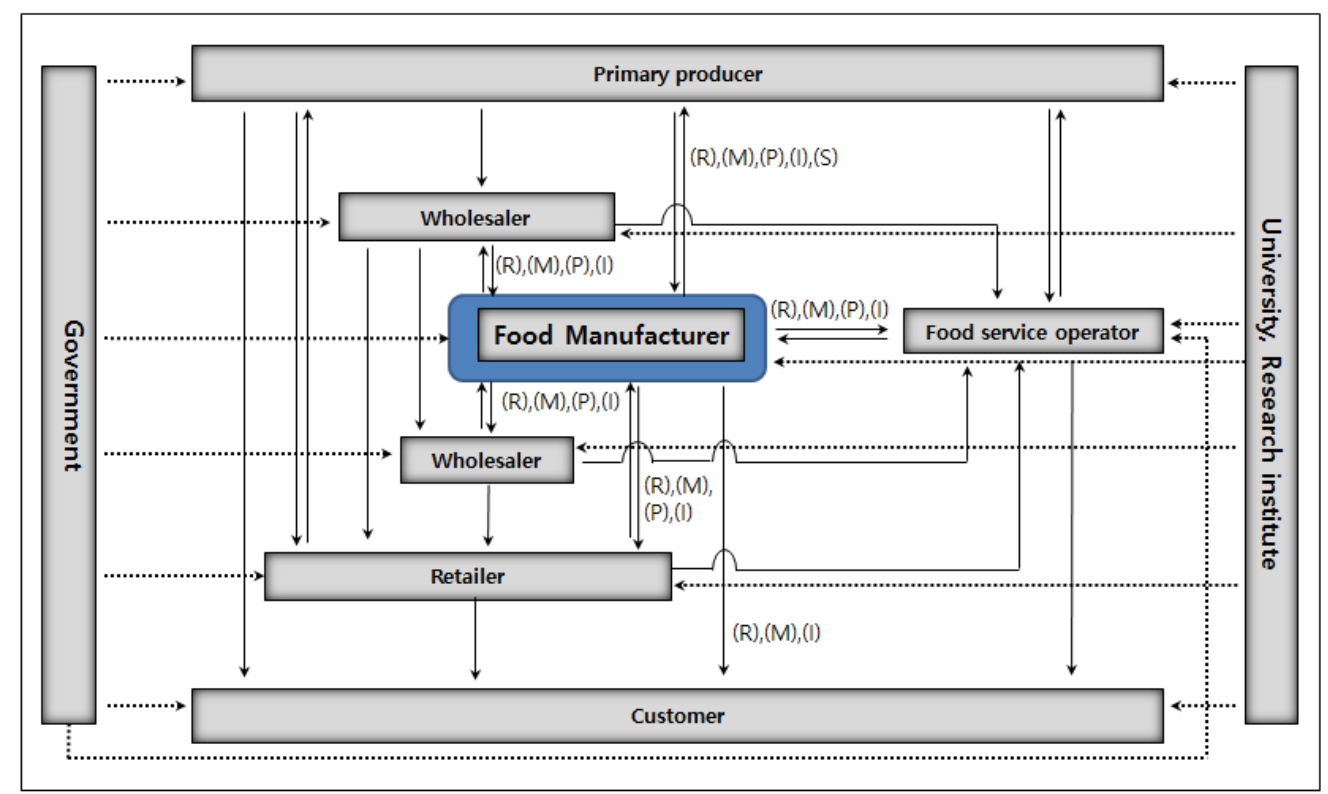

Figure 1. Food industry value chain centered on food manufacturers and expected alliances among their stakeholders. Notes: $(\mathrm{R}),(\mathrm{M}),(\mathrm{P}),(\mathrm{I})$, and $(\mathrm{S})$ indicate the purposes of alliance between two stakeholders: (R), R\&D; (M), marketing and sales; (P), production; (I), investment; (S), supply of raw materials.

Figure 1 shows the value chain of the food industry and the purpose of the alliance between food manufacturers and other stakeholders. Primary producers produce agricultural, livestock, and marine products, which are the raw materials of food, and supply them to wholesalers, food manufacturers, food service operators, retailers and customers. Food manufacturers can form alliances for all purposes with primary producers. The wholesaler, who receives raw materials from the primary producer, supplies it to food manufacturers, food service operators, downstream wholesalers, or retailers. The food service operator receives raw materials or food from primary producers, wholesalers, food manufacturers, and retailers. The retailer supplies the raw materials to the consumer. Food manufacturers can form alliances with upstream or downstream wholesalers, food service operators, retailers, $R \& D$, marketing and sales, production, and investment. Food manufacturers can form alliances with R\&D, marketing and sales, and make investments with customers. Food safety has become more important to people, therefore, governments are tightening regulations across the entire value chain of the food industry. Universities are still conducting joint research as major partners of firms $[15,16]$. Universities and governments can also play a leading role in the open innovation model [17].

A characteristic of the recent food supply chain is that the traditional value chain has been destroyed, and the route by which food reaches consumers has been diversified. First, direct transactions are increasing without going through an intermediate stage. With the development of e-commerce and courier businesses, the number of cases in which agricultural, livestock, marine products, or processed foods are delivered directly without intermediate distribution stages is increasing. Several existing intermediate distribution stages are also decreasing. However, primary producers have limitations in securing profits since a large number of supplies are still supplied through the traditional distribution stage. Second, the power of large retailers is increasing. They procure raw materials directly through primary producers. They secure price competitiveness through direct transactions with producers without going through wholesalers. Recently, the market share of private brand products produced by retailers through food manufacturing has been increasing. Third, access to food supplied by food service operators has increased. Previously, to receive a specific food service, consumers had to visit the restaurant or store directly. However, in recent years, famous food service products have been 
commercialized and can be easily seen in convenience stores or supermarkets. In particular, the food of star chefs is further stimulating consumer choice.

\subsection{Open Innovation Trends in the Food Industry}

Even in the traditionally conservative food industry, gradual innovation centering on product innovation has been influential in recent years. The food industry is generally regarded as a mature, conservative, and low-tech sector $[5,18]$. Because it is a low tech-intensive industry [19], there is less need for cooperation than in other industries, and more industries often use external sources to facilitate product development in environments where rapid technological change is standard [9]. The entry barrier of the market is low, and differentiation between products is not easy. For this reason, in the food sector, process innovation occurs more frequently than product innovation [20]. Reducing costs and improving productivity through process innovation are more advantageous to secure a competitive advantage. In recent years, however, the importance of product innovation in the food industry has also been increasing, and the trend of innovation tends to be gradual rather than radical [21]. Firms that rapidly translate consumer needs to new product development are gaining market share. According to Schiefer et al. [10], the food sector is moving from a supply-driven approach to a demand-based approach.

To innovate in the food industry successfully, a network of various stakeholders in the industry is needed. The food industry has many stakeholders in many different sectors, building various links and networks. From the farm to the dining table, it takes many paths, and there are many stakeholders involved. Building close relationships with other agents such as regulators, mediators, and end users throughout the innovation process is essential to improving public acceptance of emerging food technologies and commercial success of the resulting product [11,22]. Sarkar and Costa [23] suggested that, given the number of actors in various sectors involved in food production, innovation activities must be carefully coordinated because of the heterogeneous requirements of intermediate customers, end users, and legislators.

Open innovation started with large firms $[8,24]$, and it is advantageous for large firms to do it. Schumpeter emphasized that large corporations were given monopoly power, and they had more advantages in innovating than small businesses. Large firms also benefit from economies of scale and their scope of R\&D activities [25]. Firms protect their innovation through patents and license other firms to generate revenue [26,27]. Since large firms acquire more patents than small firms [28], it is also advantageous to generate profits from patents. Large firms are less constrained by their ability to absorb [29], as they more easily acquire people with the scientific background needed to understand, absorb, and utilize scientific discoveries and technologies developed within universities, research institutes, or firms than small and medium enterprises (SMEs). Large firms have more resources than SMEs, so it is easy to mobilize a variety of information that positively impacts product and service innovation. To effectively collaborate with various innovation partners, highly skilled knowledge workers and R\&D infrastructure are needed. Additionally, large firms' search strategies are better integrated and managed than those of small firms because large firms have a wider range of products that can use external technology simultaneously [30]. On the one hand, large firms can collaborate with partners, depending on regulatory, market, customer, user, product, and technical conditions [31]. To select the technology required for large firms, it is necessary to first create a technology roadmap [32].

\subsection{Literatures on Open Innovation and Firm Performance}

Chesbrough [24] defined "open innovation" as "the use of purposive inflows and outflows of knowledge to accelerate internal innovation, and expand the markets for external use of innovation, respectively." It is used by many firms because it is possible to increase the efficiency of R\&D and improve a firm's performance by reducing the uncertainty of technology development and shortening the time taken by using external technologies or resources $[8,33,34]$. Open innovation can 
be classified into inbound and outbound types according to the flow of technology or resources [8]. Dodgson et al. [35] classed innovation strategies as proactive, active, reactive, and passive.

Since the introduction of the concept of open innovation in 2003, the number of studies on open innovation has increased dramatically. Studies on open innovation have been mainly based on the effects of inbound or outbound innovation on a firm's performance in a cooperative network [36-39]. The relationship between cooperative form and performance $[40,41]$ and applications in various industries [42,43] were studied. Companies use open innovation strategies through external collaborations such as mergers and acquisitions (M\&As), joint ventures, joint research, and partnerships [44-46]. Lin and $\mathrm{Wu}$ [47] showed a positive relationship between alliance intensity and a firm's performance. Thanh et al. [48] found that the effect of proactive innovation was positive for a firm's performance and reactive innovation had a negative effect on it. As discussed above, although there are many studies on open innovation and firms' performance, there are few studies on open innovation and financial sustainability [49].

Yun [6] proposed open innovation dynamics to explore the interaction between different economic patterns. Open innovation has evolved from static open innovation to open innovation dynamics [50]. The dynamic model was suggested as a circling system of interactive innovations, which starts from an open innovation economy and is linked to a social innovation economy via a closed innovation economy [51]. Market open innovation provides the foundation for closed open innovation through large firms' mergers and acquisitions (M\&As), partnerships, and various open innovation channels [52].

\section{Methodology}

This study selected major food firms and conducted a case study to examine the effect of open innovation on the financial performance of the firms in the ecosystem of large food firms in Korea.

\subsection{Case Study Research}

According to Yin [53], case studies are empirical studies that investigate current phenomena in real life, especially research methods that can be used when the distinction between phenomena and context is not clear. Case studies deal with a number of variables about phenomena, collect evidence from various sources, and converge this evidence to produce new results [54]. This approach aims to numerically analyze a single instance or multiple instances of a research subject that occurred in the absence of any artificial manipulation of the research subject $[55,56]$.

Hudson [57] and Peck [58] argued that, if used properly, case studies can meet the same scientific requirements met by other research methodologies. Yin [53] said that case studies are preferred in the following cases: (1) When a question is asked about "how" or "why", (2) when the researcher has little control over the case (that is, when there is no need for control over behavioral events), and (3) when dealing mainly with contemporary phenomena. This research method explores unknown or misunderstood phenomena through exploratory investigations, leads to an expansion of understanding, and provides statistical empirical validity, but still provides empirical validity [55,56]. Case studies attempt to illuminate a series of decisions by explaining why such decisions were made, how they were implemented, and what the results were.

Despite the disadvantage that case studies are difficult to generalize, case studies in which appropriate firms are found are suitable for open innovation studies. Chesbrough $[8,24]$ started the tradition of research on open innovation, which was started on the basis of case studies of firms that study open innovation. Dodgson et al. [59] and Huston and Sakkab [30] have also conducted open innovation case studies, and this tradition continues. Case studies are applied to open innovation because open innovation focuses on qualitative changes in the innovation process. The disadvantage of case studies is that they cannot be generalized because they focus on the specific story of a specific firm. Nevertheless, open innovation is a subject that can extend existing theories through case studies. Since open innovation can have a great impact on the entire firm and industry with only 
one case, it is suitable for research on open innovation to find a suitable firm and case and conduct qualitative analysis.

\subsection{Financial Ratio Analysis}

Financial analysis includes financial ratio analysis and quantitative analysis, involving data to evaluate the firm's operational performance and financial status [60]. This study examined the financial ratio of each firm. To analyze the growth potential of firms, the net sales growth rate (NSGR) is measured. The NSGR is a representative indicator of a firm's external growth. The NSGR is the rate of growth in sales over a period [61]. If there are more sales for the year than for the previous year, the firm is judged to be external. If a firm exhibits a faster growth rate than its competitors, it means an increase in market share, so it can grasp a change in competitiveness. This ratio is influenced by two factors: Rising product prices and increasing sales volume. The NSGR is calculated as follows:

$$
\text { NSGR }=\frac{\text { current slaes }- \text { prior sales }}{\text { prior sales }} \times 100
$$

This study measured the profitability of firms through the return on assets (ROA). The ROA has been used in industry since 1919 by the DuPont Company [62]. It shows the management ability to obtain deposits at a reasonable cost and invest them in profitable investments [63]. This ratio can be broken down into the net profit and the total assets to understand the causes of change in more detail. Net profit margin refers to sales margin. The ROA is calculated as follows:

$$
\mathrm{ROA}=\frac{\text { net profit after taxes }}{\text { average total asset }} \times 100
$$

This study measured the stability of firms through the debt-to-equity ratio (DER). The DER is a representative stability index that shows the relationship between other capital and equity. The DER is debt divided by equity [64]. The lower this ratio, the more stable the financial structure. The DER is inversely related to the ratio of equity capital, so the higher the capital ratio, the lower the DER. Third-party capital refers to debts such as borrowings, corporate bonds, trade payables, outstanding payments, and provisions for debt. All firms have a different DER depending on their business characteristics and the variety of cash flows [65]. The DER is calculated as follows:

$$
\mathrm{DER}=\frac{\text { total debt }}{\text { equity }} \times 100
$$

This study used the value added ratio (VAR) as a financial productivity indication. Productivity analysis helps to assess the performance and efficiency of business activities and to understand the rationality of individual production factors' contributions and performance distributions. Recently, it has been common to measure business performance by value-added productivity. This ratio indicates the difference between the value of output produced by a firm in a period, and the value of the inputs purchased from other firms in producing the output [66]. A high VAR means that the share distributed to stakeholders is large. The VAR may increase even if the firm's profits decrease due to the expenditure of additional expenses, such as financial or labor costs. In this case, it is difficult to evaluate whether the growth foundation of the firm has been strengthened due to the increase in productivity. Therefore, when analyzing value-added productivity, it is necessary to consider changes in related costs at the same time and to interpret them in connection with profitability analysis. The VAR is calculated by dividing gross value added by net sales:

$$
\mathrm{VAR}=\frac{\text { gross value added }}{\text { net sales }} \times 100
$$


The analysis of this study presented the relationship between the total number of alliances and the change in the financial ratio during the survey period. This study observed how the financial ratio changes with the number of alliances over time. When the number of alliances increased, open innovation was considered to increase. On the other hand, when it decreased, open innovation was considered to decrease. The NSGR, ROA, DER, and VAR, which are indicators of each financial ratio, represent growth potential, profitability, stability, and productivity. An increase in the indicators except DER means a positive effect on financial sustainability. However, an increase in DER means a negative effect on financial stability and, on the contrary, a decrease in DER can be interpreted as an increase in financial stability.

\subsection{Data Collection}

This study collected data from four big Korean food firms for 11 years, from 2008 to 2018. The criteria for the selected firms are multi-national and multi-business firms among the large food firms that generate annual sales of more than USD 1 billion. To remove bias by selecting single-business firms, this study selected the firms which directly produce and sell five or more food categories. Manufacturers of feed and alcoholic beverages were excluded to focus on firms related to the original food category considering nutrition. Ten food firms with sales of more than USD 1 billion in 2018 were selected by this process. However, among them, "Samyang Corp.", which mainly produces raw material, was excluded. In addition, "Lotte Chilsung Beverage Co., Ltd." and "Lotte Confectionery", which mainly produce food in single categories, such as beverages or confectionery, were excluded. This study excluded "Lotte Foods Co., Ltd.", which has not advanced overseas. "Dongwon F\&B", which produces a specific category of the parent firm, was also excluded. Accordingly, "CJ CheilJedang Corp" (CJ), "Daesang Corporation" (Daesang), "Ottogi Coporation" (Ottogi), and "Nongshim Co., Ltd." (Nongshim) were selected. The selected firms are summarized in Table 1.

Table 1. List of selected and excluded food firms.

\begin{tabular}{cccl}
\hline Firm & 2018 Sales & Status & Reasons for Exclusion \\
\hline CJ (CheilJedang Corp) & 5494 & Selected & \\
Daesang & 2032 & Selected & \\
Lotte Chilsung Beverage & 2111 & Excluded & It produces a single category (Beverage) \\
Ottogi & 1905 & Selected & \\
Nongshim & 1688 & Selected & \\
Lotte foods & 1646 & Excluded & It has not advanced overseas \\
Samyang Corp. & 1514 & Excluded & It produces raw material \\
Dongwon F\&B & 1483 & Excluded & It is not a parent firm \\
Lotte Confectionary & 1411 & Excluded & It produces a single category \\
Maeil Dairies & 1181 & Excluded & It produces a single category (Dairy)
\end{tabular}

This study used financial data, patents, and national research data to build a basic database of alliances and performance for each of the four firms. Sales data were extracted from business reports and financial statements disclosed in the electronic disclosure system of the Financial Supervisory Service. The "Cretop Database" (http://www.kedkorea.com), built by Korea Enterprise Data, was used for growth potential, profitability, stability, and activity. Joint patents and joint research were analyzed to investigate joint research. The number of patents registered in the Korea Intellectual Property Rights Information Service (KIPRIS, http://www.kipris.or.kr), provided by the Korean Intellectual Property Office (KIPO), was used as the number of joint patent registrations. To evaluate joint research, the number of patents registered by applicants, inventors, and final rights holders was extracted simultaneously with other organizations that were not registered alone. To understand the research projects carried out jointly with the government, data from selected firms were extracted from the National Science and Technology Information Service (NTIS) of Korea's National R\&D Participating Agency Database (http://www.ntis.go.kr). 
The number of firms' alliances and mergers and acquisitions (M\&As) was collected through "Naver News Search" (http://www.news.naver.com). News articles were searched for by "firm name \& search term" for news from 14 media outlets that provide news to Naver News. This study treated each alliance as an alliance in the field of open innovation. So, this study searched following terms: partnership, M\&A, acquisition, merger, merger and acquisition, contract, agreement, business agreement, joint venture, investment, and joint research. Data on alliances and M\&As that occurred between 2008 and 2018 were collected according to the date of the alliance or M\&A specified in the article. To prevent missing data, content was added through the business reports of each firm and data published on their homepage.

\section{Results and Discussion}

\subsection{Overview of Four Large Korean Food Firms}

All four selected firms are large firms that are over 50 years old and lead the Korean processed food industry. All four selected firms were established between the 1950s and 1960s. They are large firms with more than 3000 employees. As shown in Table 2, sales of CJ are the highest with USD 5494. Daesang's sales are USD 2032, Nongshim's are USD 1688, and Ottogi's are USD 1906. Each firm produces a wide variety of foods: CJ produces 2561 items, Daesang produces 1338, Ottogi produces 1224, and Nongshim produces 582. CJ's main products are raw materials such as sugar and flour and various frozen foods. Daesang mainly produces traditional foods such as traditional Korean sauces, kimchi, and seasonings. Nongshim mainly produces ramen, snacks, and bottled water. Ottogi mainly produces noodles, such as ramen, and seasoning sauces.

Table 2. Overview of each firm.

\begin{tabular}{cccccc}
\hline Firm & Founded & Employees & Sales (USD) & Products & Main Products \\
\hline CJ & 1953 & 7298 & 5494 & 2561 & Sugar, flour, frozen food \\
Daesang & 1956 & 5001 & 2032 & 1338 & Korean sauces, kimchi, condiments \\
Nongshim & 1965 & 5053 & 1688 & 582 & Ramen, snacks, bottled water \\
Ottogi & 1969 & 3047 & 1906 & 1224 & Ramen, seasoning sauces \\
\hline
\end{tabular}

As shown in Table 3, CJ, which had the highest sales, had the most alliances with 92 cases, followed by Daesang ( 57 cases), Nongshim (33 cases), and Ottogi (13 cases). Ottogi had significantly fewer alliances than the other three firms. In particular, almost $60 \%$ of all other alliances were for R\&D. However, Ottogi had just two alliances for R\&D purposes. There are only four firm cases, but considering that they are major firms representing Korea, open innovation cannot be seen as active in the Korean food industry. Therefore, this study observed the collective effect of alliances on firms' performance by counting the total number of alliances.

Table 3. Characteristics of alliances according to open innovation purpose (2008 2018).

\begin{tabular}{ccccccc}
\hline Firm & R\&D & Marketing and Sales & Production & Investment & Supply & Total \\
\hline CJ & $54(58.7 \%)$ & $5(5.5 \%)$ & $0(0 \%)$ & $21(22.8 \%)$ & $12(13.0 \%)$ & 92 \\
Daesang & $41(71.9 \%)$ & $7(12.3 \%)$ & $2(3.5 \%)$ & $7(12.3 \%)$ & $0(0 \%)$ & 57 \\
Nongshim & $23(69.7 \%)$ & $8(24.3 \%)$ & $1(3.0 \%)$ & $0(0 \%)$ & $1(3.0 \%)$ & 33 \\
Ottogi & $2(15.4 \%)$ & $7(53.8 \%)$ & $0(0 \%)$ & $4(30.8 \%)$ & $0(0 \%)$ & 13 \\
\hline
\end{tabular}

As shown in Table 4, the firms, except Ottogi, conducted an alliance in the form of joint research and then signed an memorandum of understanding (MOU) and merger \& acquisition (M\&A). The firms created joint ventures with a ratio of 1.1 to $3.0 \%$ for 11 years for each firm except Ottogi. It can be seen that joint ventures are not active in large Korean food firms. CJ and Ottogi had a high proportion of proactive innovation [35], such as M\&As. From the above results, it can be seen that CJ, Daesang, 
and Nongshim mainly promote alliances in the form of joint research for R\&D. It can be seen that Ottogi has driven innovation through its own R\&D.

Table 4. Characteristics of alliances according to open innovation type (2008 2018, cases).

\begin{tabular}{cccccc}
\hline & MOU & Joint Research & Joint Venture & M\&A & Total \\
\hline CJ & $26(28.3 \%)$ & $47(51.1 \%)$ & $1(1.1 \%)$ & $18(19.5 \%)$ & 92 \\
Daesang & $12(21.0 \%)$ & $39(68.4 \%)$ & $1(1.8 \%)$ & $5(8.8 \%)$ & 57 \\
Nongshim & $11(33.3 \%)$ & $21(63.6 \%)$ & $1(3.1 \%)$ & $0(0 \%)$ & 33 \\
Ottogi & $9(69.2 \%)$ & $0(0 \%)$ & $0(0 \%)$ & $4(30.8 \%)$ & 13 \\
\hline
\end{tabular}

\subsection{Case 1: CJ}

As shown in Figure 2, CJ's NSGR increased as alliances increased. The DER decreased as alliances increased. The ROA tends to increase slightly as the alliances increase. The VAR increased as alliances increased. It could be interpreted that $\mathrm{CJ}$ is growing based on stability, and profitability and productivity are increasing. The results show that the financial sustainability of $C J$ is enhanced as alliances increase.

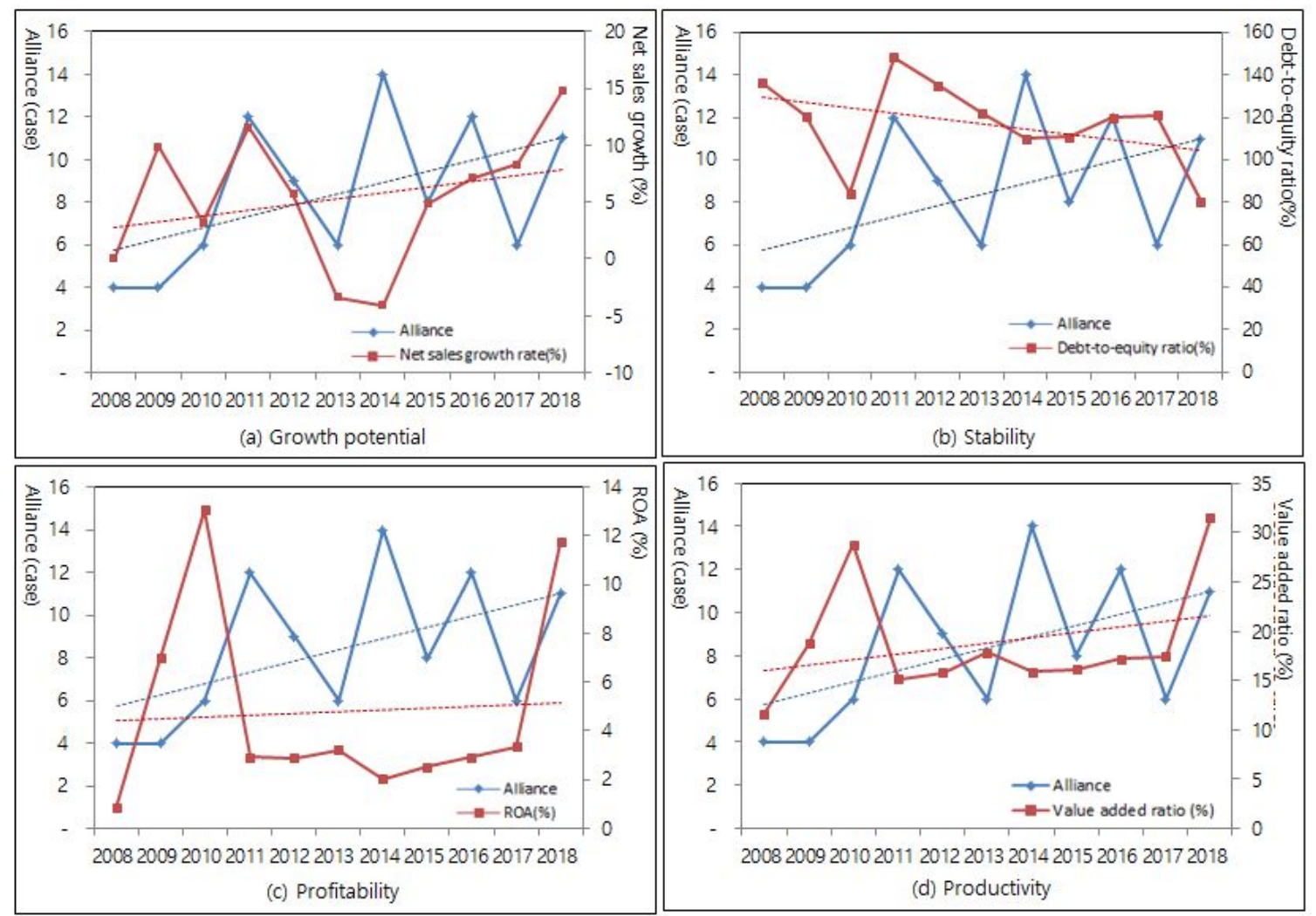

Figure 2. Analysis of CJ's financial ratio.

CJ has expanded its overseas production base and sells a variety of food materials and processed foods with potential for growth. CJ is a firm that mainly produces and sells sugar, flour, and frozen food. Raw materials such as raw sugar, wheat, soybeans, and corn are imported from overseas. As the main payment method, foreign currency borrowings such as Legacy and General Sales Manager (GSM) are used, so the exchange rate fluctuation affects profit and loss. The sugar, oil, and fats sectors require high initial investment. Three to five large firms are dividing these markets. The scale has increased by expanding overseas production bases.

Multi-national enterprises enter overseas markets and implement open innovation to secure potential markets and affordable and skilled human resources, as well as a knowledge and technology base [67]. In every year since 2008, CJ has established joint ventures in China and Southeast Asia or 
established a local production plant. A plant to make powder lysine was completed in Brazil in 2011 and in the United States in 2013. It acquired "Raviollo", a Russian frozen food firm in 2017. It acquired "Mainfrost", the German frozen food firm, and "Kahiki Foods", the American frozen food firm in 2018. Their food R\&D center was opened in the United States to develop products suitable for North America in 2016. They are continuously expanding their global business, based on the frozen food brand "Bibigo". They acquired some existing overseas frozen food firms and expanded the frozen food business.

\subsection{Case 2: Daesang}

As shown in Figure 3, Daesang's NSGR did not change significantly as the alliances increased. The DER decreased as alliances increased. It increased in ROA and VAR as alliances increased. Daesang's growth potential, stability, profitability, and productivity tended to increase. The results show that the financial sustainability of Daesang was enhanced as alliances increased.

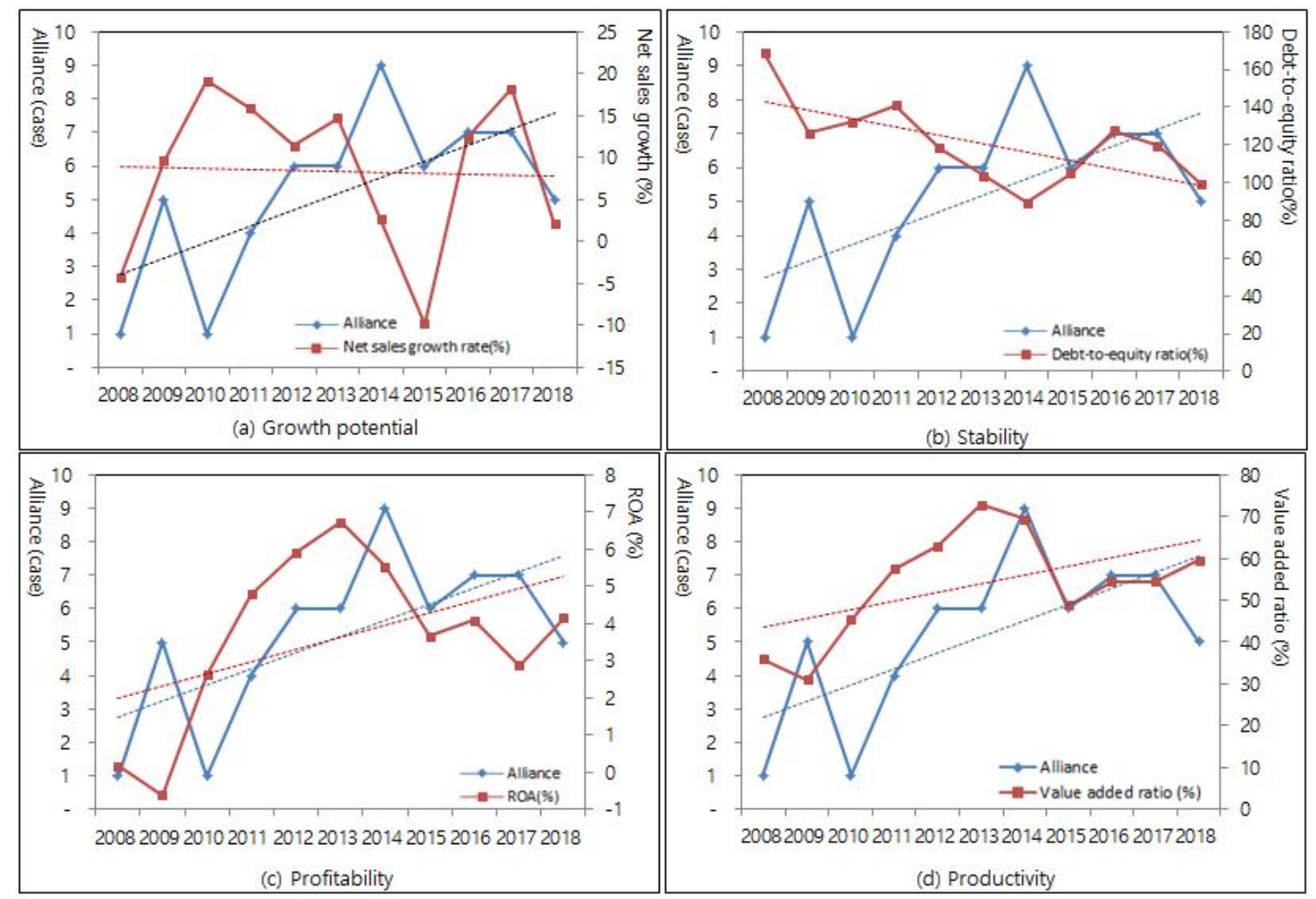

Figure 3. Analysis of Daesang's financial ratio.

Daesang has had a production base in Indonesia since it was established in 1973 and produces seasonings, a flagship item. In 2006, the firm established an additional palm oil plant in Indonesia and a starch syrup plant in the Philippines. In 2006, they signed a strategic alliance with Takeda Kirin Foods of Japan and jointly established a nucleic acid-based seasoning production firm to secure a capacity of 6000 tons per year. In 2017, a starch sugar plant was added in Indonesia. By establishing factories in Indonesia and the Philippines close to the location of raw materials, raw materials and a wide consumption market are easily secured. In addition, the production base in Southeast Asia has the advantage of being able to operate a low-cost, high-efficiency production system because the labor cost is low. After all, it plays a role in improving profitability due to cost efficiency. Starting in the mid-2000s, the size of the firm increased and its activity increased.

Daesang focused its capabilities on competitive businesses through diversification and business division coordination. Daesang acquired "Jonggajip", which mainly made kimchi, in 2006 and 
added kimchi to its flagship business. "Jonggajip" has a refrigerated distribution chain, which has strengthened the refrigeration business. In 2015, Daesang acquired the lysine division of "Baekwang Industry" to strengthen the material business. The food business and the material business grew along the axis. In 2017, the separate management of food and material business unit (BU) was introduced. In 2016, the food service business was transferred to "Daesang Bestco", a major subsidiary.

\subsection{Case 3: Nongshim}

As shown in Figure 4, Nongshim's alliances increased, but its NSGR, DER, and ROA decreased between 2008 and 2018. Although the VAR increased, it seemed that the share of distribution to stakeholders did not increase because profitability decreased. The results show that Nongshim seemed to struggle to strengthen sustainability.

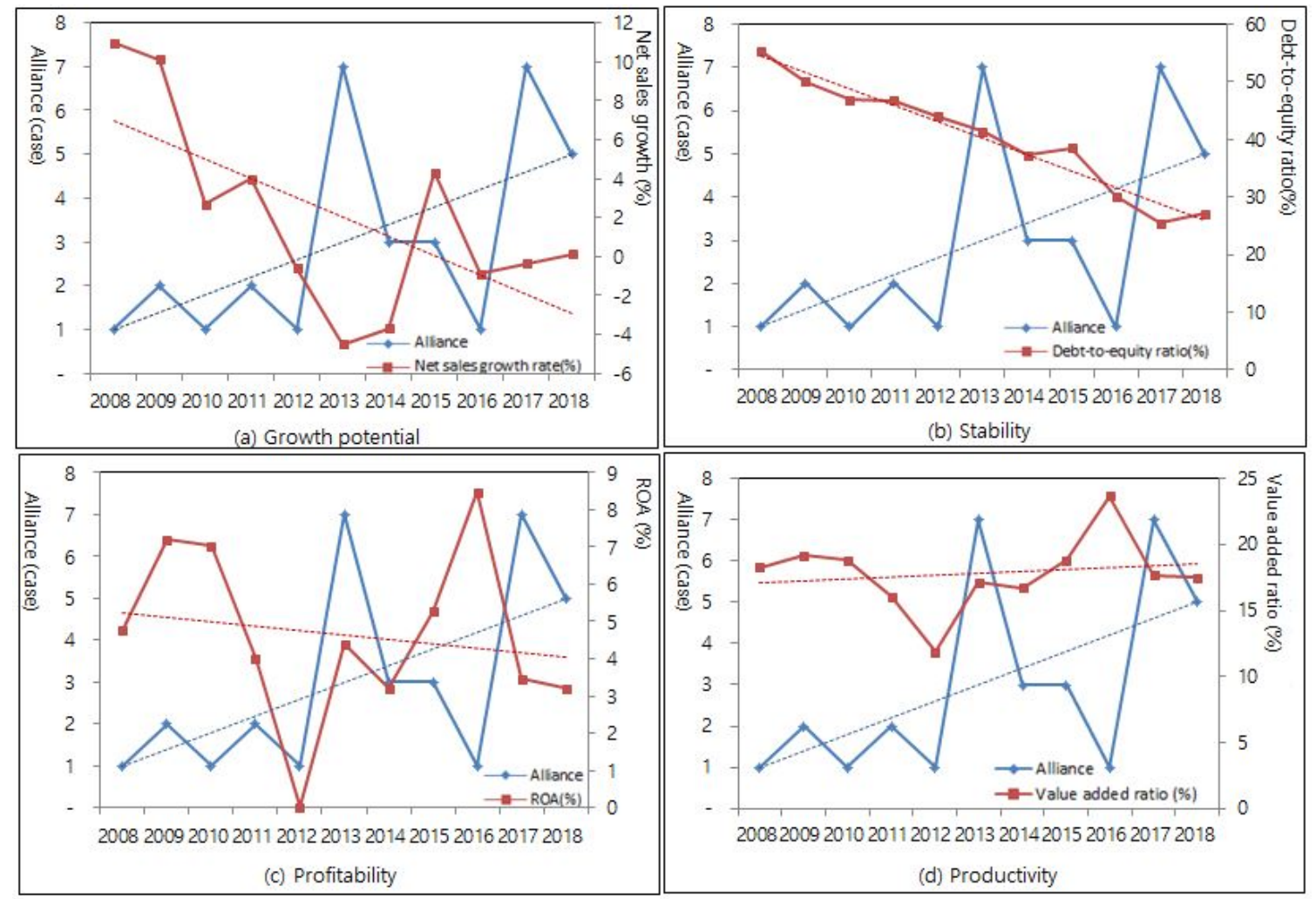

Figure 4. Analysis of Nongshim's financial ratio.

In 2011, Nongshim's bottled water accounted for $9.1 \%$ of total sales. However, in 2012, the exclusive right to sell it was recovered from the consignment agency. Since then, Nongshim's profits have decreased significantly. Nongshim's flagship product, ramen, increased its sales from $71.0 \%$ in 2008 to $75.1 \%$ in 2018 . However, Nongshim's ramen market share decreased from $70.1 \%$ in 2008 to $54.0 \%$ in 2018. Nongshim has a significantly smaller number of products compared with other large firms, so some of the top products seem to influence sales. In fact, certain products, such as ramen and snacks, dominate the entire market. However, there are few top products in other categories. In this category, it is important to maintain a brand-loyal customer, but without new innovation, it is difficult to sustain growth. Nongshim is improving its profits in overseas markets by using external alliances based on its strong brand power. In the end, Nongshim is adopting open innovation to some extent, but the internal innovation capacity does not follow. There, the open innovation strategy seems not to be synergistic in their business. 


\subsection{Case 4: Ottogi}

As shown in Figure 5, Ottogi had fewer than two alliance cases each year during the investigation period. Therefore, it is difficult to relate Ottogi's financial sustainability to alliances. Ottogi's NSGR tended to decrease over time. In terms of stability, the DER decreased. As for profitability, the ROA was between $6 \%$ and $10 \%$. As for the productivity, the VAR increased.

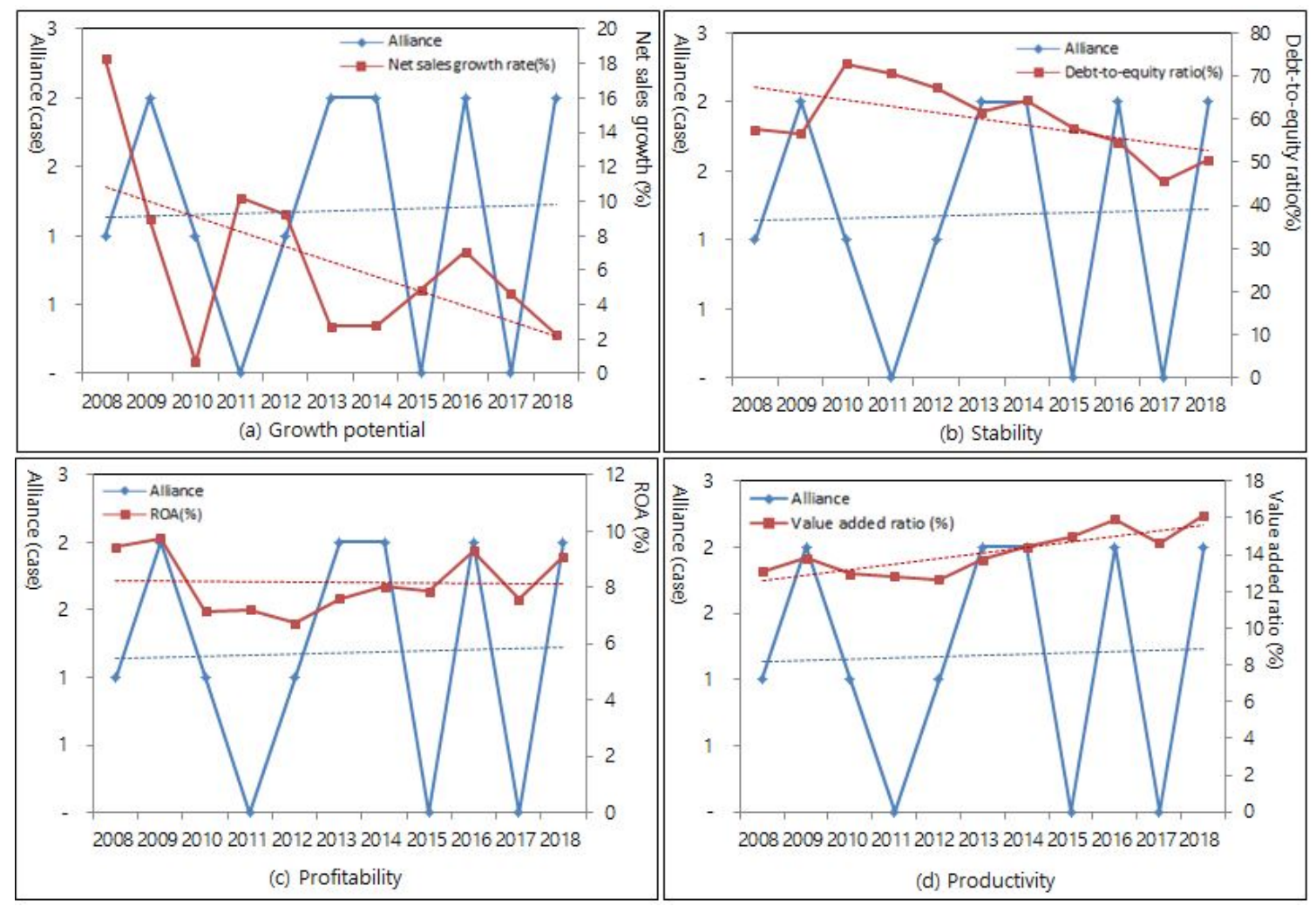

Figure 5. Analysis of Ottogi's financial ratio.

Ottogi has focused on the production of long-term preserved foods such as curry, ramen, and canned tuna, which can be cooked and eaten. Recently, the market share has been increasing with the release of frozen rice, frozen dumplings, and various instant foods. These kinds of foods are very promising products with growth prospects as households of one or two people increase. In China, there are factories that primarily process agricultural products and factories that produce some kinds of noodles. It has local subsidiaries in the United States, Vietnam, and New Zealand, and exports its products.

Ottogi had the fewest alliances with external organizations. It might have created innovative performances through internal R\&D. In the midst of the economic recession and external crisis, the key to maintaining Ottogi's growth and yield is estimated to be the result of efficient resource management and internal innovation capability. Ottogi does not attempt to engage in much open innovation, but its internal strategy has led to the firm's growth.

\subsection{Cross-Case Analysis}

The impacts on each firm's internal strategies and open innovation interactions are different. Some firms have important internal strategies, such as Ottogi, while for others, open innovation is important. Some firms, such as Daesang, apply internal strategies and open innovation synergistically.

The relationship between open innovation and financial sustainability in large Korean food firms is summarized in Table 5. As a result, growth potential and profitability increased or decreased for 
each firm. However, stability and productivity among all four firms increased, contrary to general expectations, even during the global financial crisis. CJ's case shows that the more alliances, the better the growth. However, it does not guarantee the growth of profitability. Daesang, which focused on competitive business units and conducted a lot of joint research, was observed to increase in profitability. Nongshim's growth potential and profitability were poor despite the high proportion of joint research. This example shows that even if a firm has done a lot of joint research, it cannot improve its financial performance if it lacks absorptive capacity $[27,29,68]$. In the case of Ottogi, it can be seen that a firm can maintain a constant growth rate if it stably implements its internal innovation strategy.

Table 5. Summary of financial sustainability for each firm (years: 2008 2018).

\begin{tabular}{ccccc}
\hline Firm & Growth Potential & Stability & Profitability & Productivity \\
\hline CJ & + & + & $*$ & + \\
Daesang & $*$ & + & + & + \\
Nongshim & - & + & - & + \\
Ottogi & - & + & $*$ & + \\
\hline
\end{tabular}

Notes: $(+)$ indicates that the ratio increased during the period. (-) indicates that the ratio decreased during the period. $\left(^{*}\right)$ indicates that the ratio remained constant during the period.

\section{Conclusions}

There are a few studies have been conducted on how open innovation affects the sustainable growth of the food industry. This study conducted a case study of four large food firms that had open innovation strategies. Firms signed many partnerships for R\&D. In particular, the firms had increased alliances with overseas firms and institutions to secure raw materials and open new markets. This study argued that open innovation has a positive impact on firms' performance in stability and productivity. In the view of proactive innovation [48], firms that mainly conduct proactive innovation, such as CJ and Ottogi, maintained constant profitability. In addition, this study showed that adopting open innovation to enhance financial sustainability is needed to have absorptive capacity [68].

The implications of this study are as follows. First, firms that adopt open innovation can enhance their financial sustainability through it only if they have the absorptive capability [69] to exploit the external knowledge and turn it into performance. To cope with the rapid changes in the environment, it is necessary to integrate and build firms' internal and external capacity, and quickly reconfigure as needed [70]. Second, firms that adhere to closed innovation strategies can also enhance their financial sustainability if they complement it with a proactive innovation strategy. They maintain the market's first mover advantage with a strong research orientation and dominant advantage, and continue to develop against external risks [35,48]. Leading large firms that transfer knowledge and technology to the market can form a closed economy as they gradually build internal resources and capabilities while relying on internal R\&D and protecting intellectual properity (IP) [52]. Third, the government needs to support the firm in the way of reducing regulations on firms and lowering tariffs through agreements with foreign governments to solve problems caused by imbalances in the supply of resources and market demand. Resilience has been demonstrated without direct policy support, such as the payment of direct subsidies during economic turmoil [71].

This study contributes to studying the relationship between open innovation and firms' financial sustainability as follows. As most of the existing studies were focused on the financial performance of firms, studies on the financial sustainability of firms were lacking [72]. This study expects to fill the literature gap on financial stability and profitability. In the "New Normal 2.0" era after the 2008 global financial crisis, this study using data from 2008 to 2018 could be proactively applied to the COVID-19 pandemic situation. It can help to review large firms' social investment projects by providing them with available cases regarding open innovation dynamics [51]. In addition, the DER and VAR, which are variables for analyzing financial stability and profitability, can be used as determinants for further study on open innovation and financial sustainability. 
Despite these contributions, this study has the following limitations. First, as assumed in this study, it cannot be concluded that the enhancement of financial sustainability in a firm is attributable to open innovation. Open innovation can have both positive and negative impacts on a firm's performance. Furthermore, not all improvements are because of open innovation. Second, this study has limitations in its case studies. Even if large firms are leading the food industry, the cases of four firms cannot represent the entire food industry. Third, interviews with representatives from each food firm are not included. This study is based on each firm's official business report and financial statements. However, the firms' internal situations were not confirmed through interviews with representatives of each firm.

To formulate strategies for the financial sustainability of food firms, it is necessary to identify the market trend, develop absorptive capacity, and manage the resources efficiently. Despite the findings, more research should be done on this theme. Future studies need empirical methods and to analyze more panels.

Author Contributions: Conceptualization, H.J., K.S., and E.K.; methodology, H.J.; software, H.J.; validation, K.S. and E.K.; formal analysis, H.J.; investigation, H.J.; resources, K.S.; data curation, H.J.; writing-original draft preparation, H.J.; writing — review and editing, K.S., E.K. and S.K.; visualization, H.J.; supervision, K.S.; project administration, K.S. All authors have read and agreed to the published version of the manuscript.

Funding: This study has been supported by the Ministry of Trade, Industry and Energy(MOTIE), KOREA, through the Education Program for Creative and Industrial Convergence.(Grant Number N0000717), by the Innopolis Foundation grant funded by the Korea government(Ministry of Science and ICT: MSIT) (No. 2019-DD-SB-0202-02), and by the Medical Research Information Center(MedRIC) through the National Research Foundation of Korea (NRF), funded by the Ministry of Science and ICT of Korean Government (NRF No. 2020R1A6A6018661).

Conflicts of Interest: The authors declare no conflict of interest.

\section{References}

1. Costa, L.B.M.; Filho, M.G.; Fredendall, L.D.; Paredes, F.J.G. Lean, six sigma and lean six sigma in the food industry: A systematic literature review. Trends Food Sci. Technol. 2018, 82, 122-133. [CrossRef]

2. Fritz, M.; Schiefer, G. Innovation and system dynamics in food networks. Agribusiness 2008, 24, 301-305. [CrossRef]

3. Pingali, P. Westernization of Asian diets and the transformation of food systems: Implications for research and policy. Food Policy 2007, 32, 281-298. [CrossRef]

4. Aiking, H.; De Boer, J. Food sustainability. Br. Food J. 2004, 106, 359-365. [CrossRef]

5. Galati, F.; Bigliardi, B.; Petroni, A. Open Innovation in Food Firms: Implementation Strategies, Drivers and Enabling Factors. Int. J. Innov. Manag. 2016, 20, 1650042. [CrossRef]

6. Yun, J.J. How do we conquer the growth limits of capitalism? Schumpeterian Dynamics of Open Innovation. J. Open Innov. Technol. Mark. Complex. 2015, 1, 17-20. [CrossRef]

7. Gupta, A.K.; Dey, A.R.; Shinde, C.; Mahanta, H.; Patel, C.; Patel, R.; Sahay, N.; Sahu, B.; Vivekanandan, P.; Verma, S.; et al. Theory of open inclusive innovation for reciprocal, responsive and respectful outcomes: Coping creatively with climatic and institutional risks. J. Open Innov. Technol. Mark. Complex. 2016, 2, 16. [CrossRef]

8. Chesbrough, H.W. Open Innovation: The New Imperative for Creating and Profiting from Technology; Harvard Business Press: Brighton, MA, USA, 2003.

9. Manzini, R.; Lazzarotti, V.; Pellegrini, L. How to Remain as Closed as Possible in the Open Innovation Era: The Case of Lindt \& Sprüngli. Long Range Plan. 2017, 50, 260-281. [CrossRef]

10. Fortuin, F.T.; Omta, S. (Onno) Innovation drivers and barriers in food processing. Br. Food J. 2009, 111, 839-851. [CrossRef]

11. Costa, A.I.A.; Jongen, W. New insights into consumer-led food product development. Trends Food Sci. Technol. 2006, 17, 457-465. [CrossRef]

12. Ramírez Portilla, A. The Unexpected Implications of Opening Up Innovation: A Multi-Perspective Study of the Role of Open Innovation Practices in Mature Industries; Politecnico di Milano: Milano, Italy, 2016.

13. Pyka, A.; Bogner, K.; Urmetzer, S. Productivity Slowdown, Exhausted Opportunities and the Power of Human Ingenuity-Schumpeter Meets Georgescu-Roegen. J. Open Innov. Technol. Mark. Complex. 2019, 5, 39. [CrossRef] 
14. FAO; WHO. Amended in 1991, 1999, 2001, 2003, 2005, 2008 and 2010 Regarding the General Standard for the Labelling of Pre-Packaged Foods; FAO/WHO Standards; Off. Codex Stand; FAO: Rome, Italy; WHO: Geneva, Switzerland, 2016.

15. Lee, H.-F.; Miozzo, M. How does working on university-industry collaborative projects affect science and engineering doctorates' careers? Evidence from a UK research-based university. J. Technol. Transf. 2014, 40, 293-317. [CrossRef]

16. Moon, H.; Mariadoss, B.J.; Johnson, J.L. Collaboration with higher education institutions for successful firm innovation. J. Bus. Res. 2019, 99, 534-541. [CrossRef]

17. Leydesdorff, L.; Ivanova, I. "Open innovation" and "triple helix" models of innovation: Can synergy in innovation systems be measured? J. Open Innov. Technol. Mark. Complex. 2016, 2, 1-12. [CrossRef]

18. Acosta, M.; Coronado, D.; Ferrándiz, E. Trends in the acquisition of external knowledge for innovation in the food industry. In Open Innovation in the Food and Beverage Industry; Elsevier BV: Amsterdam, The Netherlands, 2013; pp. 3-24.

19. Christensen, J.L.; Rama, R.; von Tunzelmann, N. Study on Innovation in the European Food Product and Beverages Industry: EIMS, Sprint; European Commission: Brussels, Belgium, 1996.

20. Capitanio, F.; Coppola, A.; Pascucci, S. Product and process innovation in the Italian food industry. Agribusiness 2010, 26, 503-518. [CrossRef]

21. Alarcón, S.; Sanchez, M. External and Internal R\&D, Capital Investment and Business Performance in the Spanish Agri-Food Industry. J. Agric. Econ. 2013, 64, 654-675. [CrossRef]

22. Vanhaverbeke, W.; Cloodt, M. Open Innovation in Value Networks. In Open Innovation: Researching A New Paradigm; OUP Oxford: Oxford, UK, 2006; pp. 258-281.

23. Sarkar, S.; Costa, A.I.A. Dynamics of open innovation in the food industry. Trends Food Sci. Technol. 2008, 19, 574-580. [CrossRef]

24. Chesbrough, H. Open Business Models: How to Thrive in the New Innovation Landscape; Harvard Business Press: Brighton, MA, USA, 2006.

25. Cassiman, B.; Veugelers, R. In Search of Complementarity in Innovation Strategy: Internal R\&D and External Knowledge Acquisition. Manag. Sci. 2006, 52, 68-82. [CrossRef]

26. Grindley, P.C.; Teece, D.J. Managing Intellectual Capital: Licensing and Cross-Licensing in Semiconductors and Electronics. Calif. Manag. Rev. 1997, 39, 8-41. [CrossRef]

27. Lichtenthaler, U.; Lichtenthaler, E. Technology Transfer across Organizational Boundaries: Absorptive Capacity and Desorptive Capacity. Calif. Manag. Rev. 2010, 53, 154-170. [CrossRef]

28. Klevorick, A.K.; Levin, R.C.; Nelson, R.R.; Winter, S.G. On the sources and significance of interindustry differences in technological opportunities. Res. Policy 1995, 24, 185-205. [CrossRef]

29. Cohen, W.M.; Levinthal, D.A. Absorptive Capacity: A New Perspective on Learning and Innovation. Adm. Sci. Q. 1990, 35, 128. [CrossRef]

30. Huston, L.; Sakkab, N. Connect and Develop. Harv. Bus. Rev. 2006, 84, 58-66.

31. Radziwon, A.; Bogers, M. Open innovation in SMEs: Exploring inter-organizational relationships in an ecosystem. Technol. Forecast. Soc. Chang. 2019, 146, 573-587. [CrossRef]

32. Lee, K.; Park, I.; Yoon, B. An Approach for R\&D Partner Selection in Alliances between Large Companies, and Small and Medium Enterprises (SMEs): Application of Bayesian Network and Patent Analysis. Sustainability 2016, 8, 117. [CrossRef]

33. Howells, J.; James, A.; Malik, K. The sourcing of technological knowledge: Distributed innovation processes and dynamic change. $R$ D Manag. 2003, 33, 395-409. [CrossRef]

34. Enkel, E.; Gassmann, O.; Chesbrough, H. Open R\&D and open innovation: Exploring the phenomenon. R D Manag. 2009, 39, 311-316. [CrossRef]

35. Dodgson, M.; Gann, D.M.; Salter, A. The Management of Technological Innovation: Strategy and Practice; Oxford University Press on Demand: Oxford, UK, 2008.

36. Laursen, K.; Salter, A. Open for innovation: The role of openness in explaining innovation performance among U.K. manufacturing firms. Strat. Manag. J. 2005, 27, 131-150. [CrossRef]

37. Acha, V. Open by Design: The Role of Design in Open Innovation. In Academy of Management Proceedings; August 2008; pp. 1-6. Available online: https://www.researchgate.net/publication/239657271_Open_by_ Design_The_Role_of_Design_in_Open_Innovation (accessed on 30 September 2020). 
38. Lichtenthaler, U. Open Innovation in Practice: An Analysis of Strategic Approaches to Technology Transactions. IEEE Trans. Eng. Manag. 2008, 55, 148-157. [CrossRef]

39. Gassmann, O.; Enkel, E.; Chesbrough, H. The future of open innovation. R D Manag. 2010, 40, 213-221. [CrossRef]

40. Fey, C.F.; Birkinshaw, J. External Sources of Knowledge, Governance Mode, and R\&D Performance. J. Manag. 2005, 31, 597-621. [CrossRef]

41. Foss, L.; Iakovleva, T.; Kickul, J.R.; Oftedal, E.M.; Solheim, A. Taking Innovations to Market. Int. J. Entrep. Innov. 2011, 12, 105-116. [CrossRef]

42. Chesbrough, H.; Crowther, A.K. Beyond high tech: Early adopters of open innovation in other industries. R D Manag. 2006, 36, 229-236. [CrossRef]

43. Parida, V.; Westerberg, M.; Frishammar, J. Inbound Open Innovation Activities in High-Tech SMEs: The Impact on Innovation Performance. J. Small Bus. Manag. 2012, 50, 283-309. [CrossRef]

44. Amesse, F.; Latour, R.; Rebolledo, C.; Séguin-Dulude, L. The telecommunications equipment industry in the 1990s: From alliances to mergers and acquisitions. Technovation 2004, 24, 885-897. [CrossRef]

45. Rodrigues, F.; Souza, V.; Leitão, J. Strategic coopetition of global brands: A game theory approach to 'Nike + iPod Sport Kit' co-branding. Int. J. Entrep. Ventur. 2011, 3, 435. [CrossRef]

46. Yun, J.J.; Lee, M.; Park, K.; Zhao, X. Open Innovation and Serial Entrepreneurs. Sustainability 2019, $11,5055$. [CrossRef]

47. Lin, B.-W.; Wu, C.-H. How does knowledge depth moderate the performance of internal and external knowledge sourcing strategies? Technovation 2010, 30, 582-589. [CrossRef]

48. Liem, N.T.; Khuong, N.V.; Khanh, T.H.T.; Liem, T.; Khuong, V.; Khanh, T. Firm Constraints on the Link between Proactive Innovation, Open Innovation and Firm Performance. J. Open Innov. Technol. Mark. Complex. 2019, 5, 88. [CrossRef]

49. Teirlinck, P. Configurations of strategic R\&D decisions and financial performance in small-sized and medium-sized firms. J. Bus. Res. 2017, 74, 55-65. [CrossRef]

50. Yun, J.J.; Zhao, X.; Jung, K.; Yigitcanlar, T. The Culture for Open Innovation Dynamics. Sustainability 2020, 12, 5076. [CrossRef]

51. Yun, J.J.; Park, K.; Hahm, S.D.; Kim, D. Basic Income with High Open Innovation Dynamics: The Way to the Entrepreneurial State. J. Open Innov. Technol. Mark. Complex. 2019, 5, 41. [CrossRef]

52. Yun, J.J.; Liu, Z. Micro- and Macro-Dynamics of Open Innovation with a Quadruple-Helix Model. Sustainability 2019, 11, 3301. [CrossRef]

53. Yin, R.K. Case Study Research and Applications: Design and Methods; SAGE Publications: Thousand Oaks, CA, USA, 2017.

54. Dul, J.; Hak, T. Case Study Methodology in Business Research; Informa UK Limite: London, UK, 2007.

55. Ellram, L.M. The use of the Case Study Method in Logistics Research. J. Bus. Logist. 1996, 17, 93.

56. Voss, C.; Tsikriktsis, N.; Frohlich, M. Case research in operations management. Int. J. Oper. Prod. Manag. 2002, 22, 195-219. [CrossRef]

57. Hudson, R. Fuzzy Concepts and Sloppy Thinking: Reflections on Recent Developments in Critical Regional Studies. Reg. Stud. 2003, 37, 741-746. [CrossRef]

58. Peck, J. Fuzzy Old World: A Response to Markusen. Reg. Stud. 2003, 37, 729-740. [CrossRef]

59. Dodgson, M.; Gann, D.; Salter, A. The role of technology in the shift towards open innovation: The case of Procter \& Gamble. R D Manag. 2006, 36, 333-346. [CrossRef]

60. Drake, P.P.; Fabozzi, F.J. Financial Ratio Analysis. In Encyclopedia of Financial Models; Wiley: Hoboken, NJ, USA, 2012. [CrossRef]

61. Fairfield, P.M.; Ramnath, S.; Yohn, T.L. Do Industry-Level Analyses Improve Forecasts of Financial Performance? J. Account. Res. 2009, 47, 147-178. [CrossRef]

62. Jewell, J.J.; Mankin, J.A. What is Your ROA? an Investigation of the Many Formulas for Calculating Return on Assets. Acad. Educ. Leadersh. J. 2011, 15, 79-91.

63. Badreldin, A.M. Measuring the Performance of Islamic Banks by Adapting Conventional Ratios. SSRN Electron. J. 2009. [CrossRef]

64. Lasman, D.A.; Weil, R.L. Adjusting the Debt-Equity Ratio. Financial Anal. J. 1978, 34, 49-58. [CrossRef]

65. Kamar, K. Analysis of the Effect of Return on Equity (Roe) and Debt to Equity Ratio (Der) On Stock Price on Cement Industry Listed in Indonesia Stock Exchange (Idx) In the Year of 2011-2015. IOSR J. Bus. Manag. 2017, 19, 66-76. [CrossRef] 
66. Mandal, N.; Goswami, S. Value Added Statement (VAS)-A Critical Analysis. Great Lakes Her. 2008, 2, 98-120.

67. Patra, S.K.; Krishna, V. Globalization of R\&D and open innovation: Linkages of foreign R\&D centers in India. J. Open Innov. Technol. Mark. Complex. 2015, 1, 7-24. [CrossRef]

68. Shin, K.; Kim, E.; Jeong, E. Structural Relationship and Influence between Open Innovation Capacities and Performances. Sustainability 2018, 10, 2787. [CrossRef]

69. Zahra, S.A.; George, G. Absorptive Capacity: A Review, Reconceptualization, and Extension. Acad. Manag. Rev. 2002, 27, 185-203. [CrossRef]

70. Teece, D.J.; Pisano, G.; Shuen, A. Dynamic capabilities and strategic management. Strateg. Manag. J. 1997, 18, 509-533. [CrossRef]

71. Konstantinidis, C.; Natos, D.; Mattas, K. Food and beverages industry competitiveness in economic turbulence. Br. Food J. 2019. [CrossRef]

72. Chin, S.J.I.; Karlsson, M. The Impact of Environmental Sustainability on Innovations in the Food Industry. Master's Degree, Lund University, Lund, Sweden, 8 July 2020.

(C) 2020 by the authors. Licensee MDPI, Basel, Switzerland. This article is an open access article distributed under the terms and conditions of the Creative Commons Attribution (CC BY) license (http://creativecommons.org/licenses/by/4.0/). 